Meta

Journal des traducteurs

Translators' Journal

\title{
Commentum Editoris
}

\section{Translation: A view from the outside}

\section{Rajendra Singh}

Volume 39, numéro 2, juin 1994

La traduction vue de l'extérieur - Translation: a view from the outside

URI : https://id.erudit.org/iderudit/004164ar

DOI : https://doi.org/10.7202/004164ar

Aller au sommaire du numéro

Éditeur(s)

Les Presses de l'Université de Montréal

ISSN

0026-0452 (imprimé)

1492-1421 (numérique)

Découvrir la revue

Citer ce document

Singh, R. (1994). Commentum Editoris: Translation: A view from the outside. Meta, 39(2), 305-306. https://doi.org/10.7202/004164ar d'utilisation que vous pouvez consulter en ligne.

https://apropos.erudit.org/fr/usagers/politique-dutilisation/ 


\section{COMMENTUM EDITORIS TRANSLATION: A VIEW FROM THE OUTSIDE}

RAJENDRA SINGH

Université de Montréal, Montreal, Canada

The genesis of this special issue is easy to describe. It was born as a response to some students in my department seeking help in formulating topics and subjects for graduate study, generally at the doctoral level, in what they described as "the field of translation theory". Not unfamiliar with the fact that the original science of man is founded on the assumption that confrontation with the Other is a productive, though extremely difficult, exercise, I was often left wondering why these students had never heard of Geertz (1983), let alone Quine (1960). The only thing more surprising than their unawareness of what had been gained and lost by exploring the Other from Herodotus to Said (1978) was the willingness, born out of a profound feeling, of colleagues and friends in various human and social science departments that their activities centrally and essentially involved translation. Some were kind enough to even smile and agree with my somewhat uncharitable observation that there wasn't much else involved in what they did. Quine knew this. And the post-structuralist return to the Other next door (or perhaps in the same bedroom) recognizes this. Even the addition of the concrete parameter of language as code to the enterprise of what ordinary language calls translation doesn't really change anything because, as Wittgenstein showed a long time ago, even human and social sciences other than linguistics merely play linguistic games, sometimes, or perhaps always, even blinding ones. The history of translations, as Nouss (1993) puts it, is really the translation of history, and even psychology, pace Chomsky, may be a branch of linguistics.

The best thing to do, I thought, was to invite these friends and colleagues - from disciplines from anthropology to psychoanalysis - to let those of us concerned with a particularly concrete instantiation of their problematic share their insights. One of them, Sixel, even agreed to bring to bear his holistic expertise on the human enterprise to the specific task of what some like to talk about most, the evaluation metric.

To get the best out of what I saw as the opposite of a reductionist exercise, I invited some of those colleagues of mine whom ordinary language designates as translators to respond to these observations and insights. I was fortunate enough to receive the cooperation of several sensitive and very competent colleagues. It is, however, instructive to note that the normativist orientation of the exercise normally known as translation carried enough weight for this collaborative exercise to have failed at least once. My response to that failure is that I would gladly trade any number of speakers for whom some reserve the designation "native-speakers of English" for an Achebe, a Conrad, or a Sixel. Needless to add that in translation-exercises not called by that name, the normativist orientation produces ethnocentricity. As Giles (1993) elegantly demonstrates, even the local task of "correction" of exercises actually called translation exercises is really a matter of exploring the senseform unities postulated in an exploratory fashion. Or, as generative grammarians have repeatedly argued, the task is to bring the knowledge out so that it can be talked about, and, of course, modified in the very process of coming out. 
If what I have learnt from the pieces included in this issue is a reasonable index of how rich an intellectual feast they offer, I am extremely happy to present it to both those whom ordinary language acknowledges as translators and those whom it doesn't. Although this issue is what it was intended to be - a dialogue - a real dialogue can now, hopefully, begin.

Although it is not my intention to interrupt that dialogue, I'd like to point out that I am still puzzled by the fact that despite the fact that most social-sciences seem to recognize the (counterfactual) notion of full and perfect biculturalism as a pre-condition, what we ordinarily call translation gives the impression of wanting to get away with something less, (ii) that the clarity sometimes demanded from theoretically rich explorations seems to me not very different from the clarity of style demanded by those who don't read anything at all and (iii) that the non-reducibility to diagrams of these explorations is perhaps a reflection on positivistic reifications of models furnished by the more transparently, and, therefore, perhaps more honestly, product-oriented forces of our society. Precisely how far-reaching the consequences of such models and their ancestors can be is amply demonstrated by Mahony, and precisely what the clarity in question does is seen in what we in North-America call sociolinguistics, an enterprise that seems to me to mock man's linguisticality and ridicule his sociality ( $c f$. Lele and Singh 1989). I'd also like to add that the linguist's emphasis on the structural consequences of a significantly different linguistic code needs to be counterpointed against the differences similarity hides - $c f$. Mahony on the English vs. the German Freud again. And I am sure that language planners who see translation as a way of growing will agree that it is subject to hegemonic detours. Our joint effort to democratize knowledge must include an attempt to transcend the hurdles these detours are bound to subject us to.

Needless to say that I am grateful to all my authors, the ones who went out on a limb to be scrutinized and the ones who did the scrutiny. I repeat I have learnt a lot from their exchange. To have been exclusively on the receiving end makes me feel somewhat guilty. I can, however, assure all those who have educated me that the next time a translation student knocks at my door I will know how to talk to him/her. I will pass on what I have absorbed, hopefully not entirely as a sponge. Besides, this special issue is now a public document.

I am also grateful to Paul Bandia, who helped me in the initial stages of the preparation of this issue, and to Danielle Collignon, who kept up with an ever-changing manuscript with enviable efficiency.

Last, but not least, I am grateful to André Clas, the colleague responsible for Meta, for accepting my somewhat provocative idea of a special issue in which the points were to be made by outsiders and the counterpoints by the insiders. Putting this issue together has convinced me that very pleasurable and, therefore, profitable, things can and do come out of ideas that may initially seem unusual. He must have known this when he, smilingly, said yes.

\section{REFERENCES}

GEERTZ, C. (1983): Local Knowledge, New York, Basic Books.

GILES, D. (1993): «La démarche orientée : processus dans la formation à la traduction», conférence présentée à l'Université de Montréal, 30 septembre 1993.

LELE, J. K. and R. SINGH (1989): Language and Society: Steps Towards An Integrated Theory, Leiden, E. J. Brill. NOUSS, A. (1993): "Translation - Art or Science? A Hermeneutical Reading", In Translation and Knowledge, Proceedings of the IV Scandinavian Symposium on Translation Theory, Turku, Finland.

SAID, E. (1978): Orientalism, New York, Pantheon Books.

QUINE, W. van O. (1960): Word and Object, Cambridge, Mass., Wiley and the Technology Press. 